\title{
AN ANALYSIS OF STUDENTS' MOTIVATION IN LEARNING ENGLISH AFTER GIVEN REWARDS AT THE EIGHT GRADE STUDENTS' OF SMPN 3 RAMBAH
}

\author{
Evi Kasyulita. 1), Armelida. 2) \\ Emaileviyulita23@gmail.com ${ }^{1}$ )armelida96@gmail.com.2) \\ (1 \& 2) English Study Program Faculty of Teacher Training and Education \\ University of Pasir Pengaraian 2019
}

\begin{abstract}
The purpose of this research was to find out the eight grades students' motivation in learning English after given rewards at the SMPN 3 Rambah. The students' was low motivation in learning English. This research was design a descriptive qualitative research and there were 2 instruments were used in collecting the data. There are 2 instruments that is questionnaire and interview. The researcher used three classes. There were 60 samples joined in the research. The purpose of giving the questionnaire was to find out the students motivation in learning English after given reward and interview given was purposed to find out the students' opinion of their English learning. The result of the research in the questionnaire showed that from 60 samples of the research, there were 57 students can be classified have strong motivation in learning English after given rewards and there 3 students can be classified have fair motivation. The calculation was taken from the students' answer in questionnaire and converted to the numeric score on Likert scale. Based on the finding of this research, the questionnaire score and classify it. The researcher found that the average of students questionnaire score was 78,8 and it means that their motivation averagely can be classified Good categories.
\end{abstract}

Key words: Analysis, Motivation, Reward, Learning English

\section{INTRODUCTION}

\section{Background of the Problem}

Learning English is important because nowadays many Indonesian students have interest to go abroad whether to join events or just for holiday. Teaching English for young learners is different from adult because they have very different needs, interest, abilities and enthusiast in learning language. Young learners have their own way of learning, they like to play and have fun with their friends and everything around them. When they are enjoying themselves, they are not 
always aware that they are learning language. Harmer (2001) says that unless activities are extremely engaging, they get

bored easily, losing interest after ten minutes or so. Young learners also need a motivation as their foundation in learning a language.

Motivation is an important aspect in a learning process, not only in learning a language but also in other subjects. If the teachers or the parents can motivate their students in learning something it can of course initiate their willingness in learning. Giving motivation can make the students realize the benefits and the goal of what they are learning. The motivated students can make learning as their habit and giving motivation can improve their achievement in learning.

Motivation has a close relationship with the goal of learning. Whether the students want

to study hard or not are based on their motivation in learning. If they have high motivation in learning they will have a willingness to study hard to get the goal. But if they do not have high motivation of course the students do not have willingness to study and they need more time to reach the goal of their study. So motivation is an important aspect in each student to reach the goal of study.

Motivation is a kind of supporting effort to reach the goal of the study. A student makes some efforts in learning to reach the goal in their study. A good motivation in learning can give a good achievement. In other words, the student's achievement depends on their motivation in learning. The teachers can motivate the students to improve the Learning English. Motivation is important in learning English, students can be change because motivation. According to Broussard and Garrison (2004) defined motivation as the attribute that moves us to do or not to do something. Based on the expert students can be change and doing something new. Motivation is key in language learning (Dörnyei, 1998). It is an important element that a learner needs in order for learning to take place. Students usually learn what they need or want to learn, but they have a hard time learning something which they are unmotivated for.

One of the problem, most of students have low motivation in Learning English, because some students consider that English is difficult they easily bored and lazy to learn, they also had difficult in understanding the material given by the teacher. In the case the teachers can motivate the students by giving the Rewards. For examples, sign of smiling face, star and praise. It can make students to increase motivation in learning English. In the classroom, the teacher asks some questions and the students must answer. The students who can answer the question will get the reward from the teacher. When the teacher gives reward to students who can answer the question, the other students are wants to do it because they can get the reward from the teacher. Some students shy if their entire friends get a reward and he or she 
is not, it can increase their motivation in English.

Therefore, after given rewards to students, the teachers hope that it can increase the motivation in learning English of the second grade of junior high school. The students are brave to say in English in the classroom and can answer the questions from the teacher not only to get reward but can improve their knowledge about English.

For that reason, students should master on learning English. Students think that learning English is very difficult and boring. Students lack in motivation about the learning English. The teacher must motivate the students in learning English because we know that English is a very important language in the world and English is a globalization language.

Based on the problems above, researcher want to observation the eight grades, because student lack in motivation. So, researcher giving rewards to motivation the students. so with giving rewards can improve the students in learning English. This is the reason why research entitled "An Analysis Students' Motivation In Learning English After Given Rewards At The Eight Grade Students' Of Smpn 3 Rambah".

\section{Purpose of the Problem}

The purpose of this researcher was find out the students' motivation in learning English after giving rewards at the eight grade students of SMPN 3 Rambah.

\section{REVIEW OF THE RELATED LITERATURE}

\section{Definition of Learning}

The word "learning" has some definition. Literally, learning has been defined as the ability to memorize or acquire new knowledge (Dehkhoda). in order to qualify as learning rather than just temporary gain, this process must include retention of knowledge or skill so that it can be displayed at the future.

Some of young learners in Indonesia are lazy to learn English because they think that English is a difficult subject. Shoebottom in Long (2013) also explains five factors to increase English foreign learner in learning, those are age, personality, motivation, experience, cognition and native language. This happens because the students are lack of motivation in learning a language. It is proven by the students' condition in learning process. Some of the students in the class are talking and playing around while the teacher explaining the material.

The most comprehensive definition of learning is proposed by Higar and Markowiz (1968) who define it as a relatively durable change in potential behavior conditioned on the fact that the change occurs based on experience. It should be noted that the word potential refers to learning in the person which may lead to change in behavior. This is because true learning does not occur unless the person is able to apply the things he/she has learned.

Teaching and learning has a very close relationship and one into another 
cannot be defined apart. Brown (1987: p.6) identifies the components of definition of learning as follow:

1. Learning is acquisition or getting

2. Learning is retention of information or skill

3. Retention impliesstorage systems, memory, cognitive organization

4. Learning involves active, conscious focus on and acting upon even outside or inside the organism

5. Learning is relatively permanent, but subject to forgetting

6. Learninginvolves some forms of practice, perhaps reinforced practice

7. Learning is part of changes in behavior.

\section{The Nature Of Motivation}

Motivation plays a very important role in enhancing the students' English learning performace. Gardner (1985), for a learner to be

motivated, he needs to have something to look forward to, a purpose related to goal or objective. From the statement above, motivation is a something which pushes someone to reach the goal whether in education or in any other field.

In simple terms, motivation deals with the questions of why people choose to do an activity over another, how much energy and effort they will be putting in to do the activity and how long they will continue to do the activity (Dörnyei, 2001, 2012). Motivation is the extent to which you make choice about goals to pursue and the effort you will devote to that pursuit. Motivation is key in language learning (Dörnyei,1998). It is an important element that a learner needs in order for learning to take place. Students usually learn what they need or want to learn, but they have a hard time learning something which they are unmotivated for. The learners usually decide what they would like to learn, but having said that, a teacher can also play a role in influencing the motivation of a student to a certain extent.

There are many different definitions for the term motivation. "Motivation is some kind of internal drive which pushes someone to do things in order to achieve something" (Harmer 2007:98). According to Ellliot and Covington (2001), motivation gives the reasons for people's actions, desires, and needs. Motivation can also be defined as one's direction to behavior or what causes a person to want to repeat a behavior and vice versa. According to Gardner (1985), motivation is the combination of attempt plus desire to obtain the aim of learning the language plus favorable attitudes toward learning the language. According to Brown (2000:72) "Motivation is the extent to whichyou make choices about (a) goals to pursue and (b) the effort you will devote to that pursuit".

From the definition above can be conclude that motivation is a kind of inner drive, desire, needs, and interest of someone that encourages someone to do something or to achieve 
something.

\section{A. Behavioristic Definition}

A behaviorist would define motivation as "the anticipation of reinforcement". Here psychologist like Skinner or Waston would stress the role of rewards (and perhaps punishments) in motivating behavior. In Skinner's operant conditioning model, for example, human beings, like other living organisms, will pursue a goal because they perceive a reward for doing so. This reward serves to reinforce behavior: to cause it to persist.

b) Cognitive Definition

A number of cognitive psychological viewpoints offer quite a different perspective on motivation. While rewards are very much a part of the whole picture, the difference lies in the sources of motivation and in the power of self-reward. Based on the explanation above, the researcher can conclude that motivation is the desire and effort which drive people to do anything act to achieve the goal.

From the statement above motivation is an essential factor in learning because it has an influence toward students' success or failure as language learners, so the teacher must develop an understanding of the motivation in learning.

\section{Types of Motivation}

Motivation was separated into two main types that are intrinsic motivation and extrinsic motivation. Gardner (1982:236) distinguisheds motivation into two types of motivation; intrinsic motivation and extrinsic one. We will discuss about them as follows:

a) Intrinsic Motivation

Intrinsic motivation is desire which comes from within individual to make an effort to achieve the goal. When the learners have an intrinsic motivation, they will show their attitude in the classroom such as they want to learn English because they like and enjoy learning it. According Gardner (1982) intrinsic motivation is perceived to be composed of three elements. These are effort, desire, and attitude .

People do certain activities because it gives them pleasure and develops a particular

skill based on their internal desire. According to Harmer (2007:98) "Thus a person might be motivated by the enjoyment of the learning process itself or by desire to make themselves feel better". Intrinsically motivated students are bound to do much better in classroom activities, because they are willing and eager to learn new material. Their learning experience is more meaningful, and they go deeper into the subject to fully understand it. Brown (1987:115) divided intrinsic motivation into two main types that are integrative motivation and instrumental motivations.

1) Integrative motivation is employed when learner wish to integrate themselves within the culture of the second language group, to identify themselves and 
become a part of society. For example immigration or marriage.

2) Instrumental motivation. Learner wishes to achieve goals utilizing second language. Robert Gardner and Wallace Lambert states that refer to motivation to acquire a language as means for attaining instrumental goals furthering a career, reading technical material, translation and so forth (Gardner:1987:8). This is describes a situation in which the students believe that by mastering of the target language, they will be instrumental in getting a better job, position and statutes. When the learners have intrinsic motivation, it will give a good influence to their learning.

From the statement above it is assumed than intrinsic motivation are comes from the learners itself. So, they learn English by their internal desire not from other factor from outside the learner.

\section{b) Extrinsic Motivation}

Extrinsic motivation is that which derives from the influence of some kind of external incentive, as distinct from the wish to learn for its own sake or interest in task. Harmer (2007:98) states that extrinsic motivation is the result of any number of outside factors, for example the need to pass an exam, the hope of financial reward or the possibility of future travel.
According Gardner (1982:14)

Extrinsic motivation: driven by external factors such as parental pressure, the role of teacher, environment. Many sources of extrinsic motivation are inaccessible to the influence of the teacher: for example, the desire of students to please some other authority figures such as parents, their wish to succeed in an internal exam, or peer groups influences. However, other sources are certainly affected by teacher action, Penny (1996:277). Harmer stated that external motivation has some external factors:

\section{1) The Goal}

According to Harmer (2007:99): Goal is the one of the strongest outside sources of motivation which students perceive themselves to be learning for. Frequently this is provided by a forthcoming exam, and this respect it is no surprise to note that teachers often find their exam classes more committed than other groups who do not have something definite to work towards. Here the students want to learn English because any external factors. The external factors drive the students to learn English because the students want to achieve it. For example some students have any goals when they learn English, such as they want to get a good score in final exam, they want to learn English because they want to get a good job, and they may want to continue their study overseas. 
2) The society we live in

"Outside any classroom there are attitudes to language learning and the English language in particular" Harmer (2007:999). The students want to learn English because their society. For example they learn English because they want to get prestige from the society.

3) The people around us

In addition to the culture of the world around them, students' attitudes to language learning will be greatly influenced by the people who are close them Harmer (2007:99). Learning English are very important to communicate with the peoples around the world. Sometimes people want to learn English because they feel confidence if they can mastery the English language.

4) Curiosity

We should not underestimate a student's natural curiosity. At the beginning of a term of semester, most students have at least a mild interest in who their new teacher is and what it will be like to be in his or her lessons. When students start English for the first time, most are interested (to some extent) to see what is like. This initial motivation is precious. Without it, getting a class of the ground and building rapport will be that much more difficult Harmer (2007:99).

From the statement above it is assumed than extrinsic motivation is caused by factors from outside from student. It can be from teacher, parent, and environment. In this research the researcher only focused at the external motivation.

\section{Reward}

Reward is an educational strategy which can be used to make the students feel happy in learning a language and also can be used to give motivation to the students for learning better. Cotton (1988), Defined the use rewards in the classroom as "instructional reinforcement", which is the provision of verbal, symbolic, tangible, or other rewards for desirable academic or effort at the classroom. From the statement above reward is to motivate the children to exhibit desirable behavior, work ethic and interpersonal skills throughout the school day, both inside and outside the classroom environment.

The explanation is rewards, as a form of external motivation, can supplement the internal drive to assist students in achieving their goals as rewards appeal to them and in turn promote excellence (Bafile, 2003; Cotton, 1995 \& Cowell \& Butler, 1987). If a student is not intrinsically motivated to do well, using extrinsic motivators such as rewards or punishments can sometimes prod the student into action (Brophy, 1998). That is, rewarding is very important to teaching activities.

Students' motivation to learn however may also be dependent on their anticipation of reward. According to Skinner (cited in 
Brown, 2001, [57-58]) one of the most powerful factors in directing one's behavior to the goal that is set by a student could be the anticipation of reward. Brown (1994) defined intrinsic motivation as activities that one does without expecting any apparent reward except for the activity itself. Intrinsic motivation stems from the student's needs, wants, or desires and so external reward is not necessary.

The application of rewards by teachers must observe the following principles (Stan, 2004, p.67):

1. if the pupil is told what it is received for, the strengthening is more efficient;

2. purposes must be strengthened on a short term basis, so that the pupil can make the connection between the behavior wished from it and the strengthening;

3. the strengthening must not be granted to counterbalance reprimands for previous facts; it must be the consequence of the pupil's behavior;

4. reward must be granted in time and not with delay (in order for the pupil to establish the same connection);

5. the granting of rewards may be made for a set of actions or contents.

Taking into account that rewards shall lose their value in time, the teacher must announce in good time which is the structure of contents or actions for which that reward type is given. It is important to use rewards that will motivate the children and incentivise them. The type of rewards to use is always an important choice for teachers.

Cotton (1988) outlined five types of rewards to give children:

1.Praise/Verbal reinforcement Symbolic rewards (giving children certificates or medals signifying an achievement)

2. Token rewards (Tokens, that when accumulated can win prizes)

3. Tangible rewards (Tactile rewards such as sweets, toys or school supplies)/

4. Activity rewards. (Allowing the children free time to do activities)

From that statement about I conclude that reward is a how to make the students interest in learning and also can be give student motivation to the students for learning better. It is important to use rewards that will motivate the children and incentivise them.

\section{RESEARCH METHODOLOGY}

\section{The Research Design}

This research has designed as a descriptive qualitative design. According to Sugiyono (2017:8), Qualitative research methods are often called naturalistic research methods because their research is carried out in natural setting. Qualitative descriptive study is a part of a qualitative research. The purpose of descriptive qualitative research was to find the result of analysis. In this research, the researcher want to analyze students' 
motivation in learning English after given rewards at the eight grade students' of SMPN 3 Rambah.

\section{Technique of Collecting The Data}

According

Sugiyono

(2017:224) Techniques of collecting the data are the most strategic step in research, because the main purpose of research is to obtain data". The data collection in this study is questionnaire and interview.

To collect the data for this research, researcher used questionnaire and interview. The researcher gave a questionnaire to students, with

45 minutes to answer questionnaire. And the item questionnaire were translated to Indonesia. Then, the researcher calculated to find out the level of students motivation in this research.

Then, the researcher gave an interview to the all samples of this research.

\section{Technique of Analyzing The Data}

Data analysis is important, because throught the data researcher have the benefit, and in problem solution and get the final research. According Spradley (1980) analysis of any kind involve a way thinking. It refers to the systematic examination of something to determine its parts, the reation among parts, and the relationshipto the whole. Analysis ia a research for patterns.

The research used descriptive used descriptive method aims to collect information on students' motivation in learning English after given rewards at the eight grade at the SMPN 3 Rambah. This research was conduct with descriptive analysis, with the following :

1. Collecting the data in using questionnaire

2. Conducting interviews to support the data obtained through questionnaires

The technique the Analyzing Data in this Reseach as follows:

a. Identification of students' answer throught questionnaire

To know the students' motivation in learning English, researcher used a questionnaire. The students answered the questionnaire using liker, the liker have positive and negative statement. The researcher saw for score of statement and then the score change be percentage. To measure students' motivation, the researcher used the following table of motivation category.

\section{Table 5: Category of Motivation in learning}

\begin{tabular}{|c|c|c|}
\hline $\mathbf{N}$ & Motivation in & Category \\
$\mathbf{O}$ & $\begin{array}{c}\text { learning } \\
\text { English }\end{array}$ & \\
\hline 1 & $80-100$ & Very good \\
\hline
\end{tabular}




\begin{tabular}{|c|c|c|}
\hline 2 & $65-79.9$ & $\begin{array}{c}\text { Goo } \\
\text { d }\end{array}$ \\
\hline 3 & $55-64,9$ & Fair \\
\hline 4 & $40-54,9$ & Low \\
\hline 5 & $00-39,9$ & Very low \\
\hline
\end{tabular}

Arikunto (2007)

b. Identification of students' answer throught interview

To know the students' motivation in English learning, researcher used the interview. From this technique, the researcher were able to describe students' motivation on learning English after given reward at the eight grade at the SMPN 3 Rambah.

\section{FINDINGS AND DISCUSSION}

Based on the result of the research from questionnaire, there are 57 students can be classified have strong motivation in learning English after given rewards and 3 students can be classified have fair motivation. Based on the finding in this research, the researcher calculated the total score to find out the average and the researcher use likert scale to answer questionnaire. The researcher found that the average of students' questionnaire score was $\mathbf{7 8 , 8}$ and it means that their motivation as the Good.

It means that the given rewards to motivation in learning English to the students an improvement toward their motivation in learning English. After given rewards in learning English, students became more interested and motivated.
The researcher also gave 5 questions in interview to support the data of this research. The questions related to the students' effort in improving their English skill, their expectation learning English, their motivation in learning English through given rewards, how often their teacher given rewards in learning English and support from their parents in learning English.

From the students' answer in the interview sheets, the researcher conclude that most of the students will study hard and diligently to improve their English skill. Students expect by learning English they are able to understand more about English and able to speak English. Most of them also answered the become more motivated in learning English through given rewards. Most of the students answered that the teacher given motivation in learning English is sometimes. Finally all the students answered that their parents support them in learning English. So, it can be concluded that students' motivation in learning English can be improved well by the support from the neighborhood and after given rewards in learning English.

The result above is supported by the statement of Cotton (1988), Defined the use rewards in the 
classroom as "instructional reinforcement", which is "the provision of verbal, symbolic, tangible, or other rewards for desirable academic or effort at the classroom.

In addition Gardner (1985), for a learner to be motivated, he needs to have something to look forward to, a purpose related to goal or objective. Meanwhile, Brown (2000:72) Motivation is the extent to which you make choices about (a) goals to pursue and (b) the effort you will devote to that pursuit.

Gardner (1982:14) Extrinsic motivation: driven by external factors such as parental pressure, the role of teacher, environment. So, the results obtained from this researcher from a questionnaire and interview that the reward given by the teacher is the motivating the student in learning English.

\section{Conclusion}

The finding of the result research showed, there are 57 students can be classified have strong motivation in learning English after given rewards and 3 students can be classified have fair motivation. The calculation was teken from the students' answer in questionnaire and converted to the numeric score on Liker scale. Based on the finding of this research, the researcher calculated the total score to find out the average questionnaire score and classify it. The researcher found that the average of students' questionnaire score was $\mathbf{7 8 , 8}$ and it means that their motivation as Good.

From the students' answer in the interview sheets, the researcher conclude that most of the students answered they became more motivated in English learning through given rewards. Most of the students became more interested to pay their attention after given rewards. So, it can be concluded that students' motivation in learning English can be improved well by the support from the neighborhood and after given rewards in learning English.

\section{Suggestion}

Based on the result of the research, researcher would like to give some suggestion below:

1. For English teachers, the teachers are suggested to apply the strategy to attract the students' motivation to improve their English. They need to be motivated that English is important to be mastered in verbal or written communication.

2. For students, English is a very important to be mastered to support your career or education in the future. Today many countries provide scholarships abroad. So it is very useful for those of us who have good English skills.

3. For the next researcher, hopes that the result of the research may be as the reference to the following this research with different population, sample, 
methodology, and instrumentation. The researcher suggesting to find out the other relevant, especially in observe the students' motivation in learning English to the University or senior high school students.

\section{ACKNOWLEDGEMENT}

The researcher also want to express her sincere thank to both of her advisor. Firstly for Evi Kasyulita,M.Pd as the first advisor who with her patience always gives her ideas, time, and useful suggestion for her. Secondly for Batdal Niati.M.Pd as the second advisor who gives her the correction, advice,time and suggestion, so thereseacher can finish this article well.

\section{BIBLIOGRAPHY}

A. Howlin, Conor, (2015) The Merits Of Using Rewards Strategies In The Classroom And How To Maximize Their Effectiveness; Vol. 1. ISSN 6977.

Anthuis, Michelle (2013) The Effect Of Extrinsic Rewards and Intrinsic Motivation on Student Reading and Learning. University of Central Missouri Warrensburg, Missouri.

Alizadeh, Mitra (2016) The Impact Of Motivation On English Language Learning; Vol. 1, No.1.
Brown, H. Douglas (1994) Teaching by Principles : An Interactive Approach to Language Pedagogy. San Fransisco State University. Englewood Cliffs, New Jersey.

Brown, H. Douglas (2000) Teaching by Principles : An Interactive Approach to Language Pedagogy Second Edition. San Fransisco State University. Englewood Cliffs, New Jersey.

Gardner. (2004) The Attitude/Motivation test Battery : International AMTB Research Project, The University of Western Ontario, Canada.

Gardner R.C. (2007) Motivation and Second Language Acquisition. University of Western Ontario. ISBN: 1697-7467.

Gardner R.C. (1985) Social Psychology and Second Language Learning: The Role of Attitudes and Motivation. London, : GB: Edward Arnold.

Irawati (2016) The Use Of Reward And Punishment To Increase Young

Learning English As Foreign Language Adapted To Indonesia Context; Vol. 5, No. 1. ISSN 2302-3198.

Juniar, Rima (2016) The Role Motivation In Learning English For Indonesian Students; Vol, 2, Issue. 8. ISSN 23947926. 
Khajehpour, Milad (2011) Attitudes and Motivation in Learning English as Second Language in High School Students; 15-ISSN 1209-1213.

Langa, Claudiu (2014) Rewards And Punishments Role in TeacherStudent Relationship From The Mentor's Perspective; Vol. 7, No. 4, 2014. ISSN 2065-1430.

Mercè Bernaus, Annie Wilson \& Robert C. Gardner (2009) Teachers' Motivation, Classroom Strategy Use, Students' Motivation and Second Language Achievement. Multilingual Education in Europe: Policy Developments PORTALINGUARUM12, junio 2009 pp. 25-36 ISSN: 1697-7467.

Mahadi (2012) Motivation, Its Types, and Impact in Language Learning; Vol. 3, No.24.

Mantiri, Oktavian (2015) Priciples in Language Learning Motivation; 2015.030206.

Mansorihasanabadi (2016) The Role Of Reward And Punishment In Learning; Vol.7, No. 2. ISSN 0976-2612.

Nunan, David (1991) Language Teaching Methodology. Macquarie University, Sydney.

Saranraj, L (2016) Motivation in Second Language Learning A Retrospect; Vol.4 (1), January (2016), Pp. 7-13. ISSN 2347-6915.
Sugiyono, Prof. Dr (2017) Metode Penelitian : Kuantitatif, Kualitatif, dan R\&D. Bandung : Alfabeta.

Ur, Penny (1995) A Course In Language Teaching: Practice And Theory. Cambridge University.

Phat, Loi, Do \& Thi, Loc, Uyen, Nguyen (2016) Motivatin EFL Classroom Participation By Rewarding At A Language Center In Ho Chi Minh City, Vietnam; Vol. 3, 4Issue. 5. ISSN 2376-760X. 
Balnk Page 